\title{
ORIENTASI DALAM PEMBANGUNAN SUBSTANSI HUKUM PIDANA PENJARA BAGI ANAK NAKAL
}

\author{
Alikuddin Saragih \\ Dosen Fakultas Hukum Universitas Widya Gama Mahakam Samarinda
}

\begin{abstract}
ABSTRAK
Substansi undang-undang dilatarbelakangi paradigma yang ada dan berkembang saat itu, juga merupakan ekspresi hukum dalam suatu masyarakat, yang memiliki keterbatasan dan selalu berubah mengikuti kebutuhan dan perkembangan hukum suatu masyarakat, demikian juga tentang ketentuan pidana penjara bagi anak yang melakukan tindak pidana.
\end{abstract}

Kata Kunci : Hukum Pidana Penjara, Anak

\section{PENDAHULUAN}

Pembangunan hukum merupakan rangkaian kegiatan dan usaha yang terdiri dari langkah strategis yang dituangkan dalam semua program dan proyek pembangunan hukum, hingga seluruh kegiatannya dilaksanakan menurut pola dan mekanisme yang terarah, sikron, terpadu dan realitis serta dapat mengantisipasi perkembangan kebutuhan pembangunan dan aspirasi masyarakat di masa datang, guna menunjang, mengiringi, mengarahkan dan mengamankan perubahan masyarakat dalam rangka pembangunan manusia Indonesia seutuhnya dan pembangunan seluruh masyarakat Indonesia.

Paradigma pembangunan hukum di Indonesia membutuhkan perumusan yang ekstra hati-hati karena membutuhkan kajian yang komprehensif, baik dilihat dari sisi sektor, bentuk, dan sasaran pembangunan hukum tersebut. Selain harus memperhatikan sisi dinamikanya, heterogenitas yang terkandung dalam komponenkomponen pendukung sistem hukum nasional pun wajib diberi tempat secara tepat dan proporsional dalam perumusan paradigma pembangunan hukum tersebut.

Hukum memang dapat difungsikan sebagai sarana untuk memperbarui masyarakat (social engineering). Namun, perekayasaan sosial seperti itu membutuhkan dukungan penelitian yang mendalam tentang hukum yang hidup di masyarakat (living law) dan tingkat kesiapan masyarakat dalam menyikapi pembaruan yang akan dilakukan melalui sarana hukum itu.

Problematika yang tampak, institusi negara memprioritaskan pada legal drafting, sedangkan kelompok masyarakat memprioritaskan advokasi hak-hak masyarakat. Pada sisi lain institusi negara memprioritaskan pada sektor keuangan, sedangkan kelompok masyarakat memprioritaskan pada sektor pengadilan. Masih kental bahwa pembangunan hukum lebih identik dengan pembuatan hukum.

Penjatuhan pidana penjara terhadap anak, merupakan salah satu penerapan dari jenis pidana yang dikenal di dalam hukum pidana dengan sanksinya berupa pidana penjara, sebagai upaya dalam penanggulangan kejahatan anak. Menurut H.L.Packer, penggunaan upaya pidana tersebut sampai saat ini masih sering dipersoalkan dalam 
peranannya menghadapi masalah kejahatan sebagaimana dikemukakan:"Usaha pengendalian perbuatan anti sosial dengan pidana pada seseorang yang bersalah melanggar peraturan pidana, merupakan problem sosial yang mempunyai dimensi hukum yang penting" (dalam Arief Barda Nawawi, 1996:17). Dalam Jurnal Crime and Delinquency Volume: 45 dikemukakan oleh Pamala L. Griset, juga menyatakan adanya berbagai masalah yang ditemukan dalam penelitian berkaitan dengan penjatuhan pidana, sebagaimana dinyatakan:

"This study focuses on sentence completion and recidivism of juvenelies Referred to teen courts for disposition by their peers as an alternative to judicial sentencing. More than 70 percent of the referrals completed their sentences, and just less than a third recidivate over a 1-yeqar follow-up. In multivariate models, sentence completion was significantly less likely among persons sentenced" (Pamala L. Griset dalam Jurnal Vol. 45,1999.467.

Dalam terjemahan bebasnya, disampaikan bahwa studi ini memfokuskan perlunya pembaharuan dalam penjatuhan pidana dan para resivis anak nakal, dimana menunjukkan pada 10 (sepuluh) pengadilan untuk menempatkan mereka sebagai suatu alternatif dalam proses peradilan untuk penjatuhan pidana. Ada lebih dari 70 (tujuh puluh) persen dari mereka dikenakan alternatif tersebut dan hanya tiga orang yang dijatuhi pidana lebih dari 1 (satu) tahun. Dalam berbagai model penyempurnaan pemidanaan ditandai dengan semakin berkurangnya orang -orang yang dipidana.

Sehubungan dengan penjatuhan pidana, pandangan para penyusun Wetboek van Strafrecht yang telah tersusun pada tahun 1881, didasarkan pada pemikiran, bahwa anak yang berumur antara sepuluh sampai dua belas tahun adalah wajar jika mereka tidak dapat berbicara tentang adanya suatu pengetahuan yeng tepat mengenai baik dan buruk, tentang hal-hal yang dibenarkan atau tidak dan tentang hak atau melawan hak. Dengan demikian mereka tidak dapat dipertanggungjawabkan. Sedang bagi mereka yang telah berumur di atas 10 (sepuluh tahun) sampai dengan 16 (enam belas tahun) dipandang telah mampu menilai dan menyadari tentang perbuatannya, sehingga dinyatakan dapat dipertanggungjawabkan atas perbuatan mereka, apabila dapat dibuktikan secara menyakinkan. Hal ini dapat dibaca dalam Pasal 38 dan Pasal 39 Wetboek van Strafrecht (KUHP Belanda) pada tahun 1881, menentukan sebagai berikut ;

"Bahwa anak-anak tidak dapat dituntut menurut hukum pidana, apabila ia sebelum mencapai umur 10 tahun telah melakukan tindak pidana; Jika seorang anak telah berumur sepuluh tahun atau lebih akan tetapi belum mencapai umur enam belas tahun telah melakukan kejahatan itu, pelaku dapat membuat suatu oordeel des onderscheids atau tidak, artinya apakah pelaku dapat membuat penilaian mengenai perbuatannya. Apabila pelaku tidak dapat membuat suatu penilaian mengenai perbuatannya, yaitu apakah perbuatannya dapat dibenarkan atau tidak, maka bagi pelaku tidak dapat dijatuhi pidana yang berat, maka hakim dapat memerintahkan agar pelakunya dimasukkan kedalam lembaga pendidikan" (Made Sadhi Astuti,1997:21).

Dalam perkembangan berikutnya sejak tahun 1901, pertanggungjawaban anak menurut hukum Belanda, tentang kriteria dapat atau tidaknya anak membedakan yang baik dan yang buruk dari suatu perbuatan telah ditinggalkan. Penggunaan pidana penjara sebagai cara untuk menghukum para penjahat baru dimulai dalam akhir perkembangan abad 18 yang bersumber pada paham individualisme. Dengan berkembangnya paham individualisme maka pidana penjara semakin memegang peran 
penting dan menggeser kedudukan pidana mati dan pidana badan yang dipandang kejam (Ninik Widiyanti dan Yulius Waskita, 1987:64)

Dengan landasan dan semangat negara hukum dalam arti materiil itu, setiap tindakan negara haruslah mempertimbangkan dua kepentingan ataupun landasan, yaitu kegunaannya (doelmatgheid) dan landasan hukumnya (rechtmatigheid), harus selalu diusahakan agar setiap tindakan negara (pemerintah) itu selalu memenuhi dua kepentingan atau landasan tersebut (BP-7 Pusat, 1990: 53).

Mengenai masalah efektivitas ini RM. Jacson mengemukakan: "bahwa pidana penjara termasuk jenis pidana yang relative kurang efektif. Berdasarkan studi perbandingan, bahwa angka perbandingan rata-rata penanggulangan atau penghukuman kembali bagi orang yang pertama kali melakukan kejahatan berbanding terbalik dengan usia sipelaku" (RM. Jackson, 1972:306).

Kritik terhadap segi-segi negative dari pidana penjara, telah menimbulkan gelombang usaha untuk mencari bentuk-bentuk alternative dari pidana penjara. Sementara itu, usaha tersebut dibarengi dengan adanya kecendrungan dalam praktek untuk menghindari atau membatasi pidana penjara serta usaha untuk memperbaiki pelaksanaannya. Dampak tersebut juga dinyatakan, the case study's implication for the issues at hand, inmate-balance theory holds that authority cannot be taken away from inmates, however skilled the effort, because shared authority is the essential element of prison stability. If this assumption is relaxed-taking away authority may generate tensions-the argument becomes more reasonable and administrative-control theory can be brought to bear (Bert Useem dan Michael D.Reisig dalam Journal. 1999:755)

Dewasa ini dalam perkembangan ada kecenderungan penjatuhan pidana sedang berubah dan memang seharusnya memerlukan perubahan sesuai dengan perubahan dalam masyarakat. Perubahan ini tidak hanya mengenai perbuatan apa saja yang merupakan atau dinyatakan sebagai kejahatan, tetapi juga mengenai jenis pidana untuk suatu kejahatan, karena gagasan-gagasan mengenai pidana juga telah berubah sesuai dengan perubahan-perubahan itu sendiri terutama mengenai pandangan hidup tentang moral dan kemasyarakatan (S. Balakhrisnan, 1973:4)

Pelaksanaan pidana penjara terhadap anak masih merupakan dilema saat ini, karena masih banyak terpidana anak tidak ditempatkan pada LAPAS anak, sebagai contoh untuk propinsi Kalimantan Timur terpidana anak ditempatkan pada Lapas dewasa dan beberapa diantaranya masih dititipkan di berbagai Rumah Tahanan Negara yang ada di daerah Kalimantan Timur.

Dalam hal ini reorientasi terhadap resosialisasi pidana penjara patut diperhatikan lebih dini khusus terhadap anak disamping masih pada kondisi yang labil dalam pertumbuhannya, sehingga penjatuhan pidana penjara dapat memberikan manfaat dalam perbaikan anak dan menumbuhkan rasa kesusilaan serta dapat memiliki rasa tanggung jawab dirinya di dalam masyarakat dikemudian hari.

\section{PERMASALAHAN}

Dari pokok pemikiran yang dikemukakan diatas, dapat diajukan beberapa persoalan mendasar yang akan dikembangkan lebih lanjut dalam menelaah pidana penjara terhadap anak dalam kerangka pembangunan substansi hukum dalam peradilan pidana pidana anak, sebagai upaya pencegahan dan penanggulanaan kejahatan, dengan ruang lingkup masalah yang dirumuskan sebagai berikut. 
1. Bagaimana penerapan hukuman pidana penjara untuk anak dalam sistem peradilan pidana anak.

2. Pembangunan substansi hukum pidana penjara bagi anak dan pencegahan kejahatan terhadap anak nakal.

\section{DEFINISI OPERASIONAL}

1. Pengadilan anak adalah pelaksana kekuasaan kehakiman yang berada di lingkungan peradilan umum (Pasal 2, Undang-undang Nomor 3 Tahun 1997). Pasal 3 Undang-undang Nomor 3 Tahun 1997 menyatakan bahwa siding anak bertugas dan berwenang memeriksa, memutuskan dan menyelesaikan perkara anak sebagaimana ditentukan dalam Undang-undang. Pasal 21 menegaskan bahwa sidang anak berwenang untuk memeriksa, memutuskan dan menyelesaikan perkara pidana dalam perkara anak nakal.

2. Pengertian Anak Nakal dimaksud adalah menurut Undang-undang No.3 Tahun 1997, memberikan perumusan dalam Pasal 1 ayat 2, adalah sebagai berikut :

a. anak yang melakukan tindak pidana; atau

b. anak yang melakukan perbuatan yang dinyatakan terlarang bagi anak, baik menurut peraturan perundang-undangan maupun menurut peraturan hukum lain yang hidup dan berlaku dalam masyarakat yang bersangkutan.

\section{PEMBAHASAN}

\section{A. Penjatuhan Pidana}

Pembahasan tentang pidana di dalam lapangan hukum pidana, mendapat perhatian khusus para praktisi hukum dalam keterkaiatannya dengan tugasnya melakukan penegakan hukum pidana. Secara definitive dikenal beberapa pendapat para ahli hukum yang merumuskan tentang pengertian pidana. Pidana dapat dikatakan merupakan sanksi negatif yang diberikan kepada orang yang telah terbukti bersalah atau dapat dipertanggung jawabkan dalam hukum pidana atas tindak pidana yang dilakukan. Roeslan Saleh berpendapat bahwa "pidana adalah reaksi atas delik, dan ini berwujud suatu nestapa yang dengan sengaja dilimpahkan negara pada pembuat delik itu" (dalam Arief Barda Nawawi, 1992:2).

Penggunaan istilah penjatuhan pidana adalah sangat terkait dan bagian dari pemidanaan yang menunjukkan ada hubungan dengan penyelesaian suatu perkara pidana oleh hakim, yang kerap kali sinonim dengan pemidanaan, memiliki arti yang sama dengan pemberian atau penjatuhan pidana oleh hakim (Soedarto, 1982:5). Pemidanaan bila diartikan secara luas adalah sebagai suatu "proses pemberian atau penjatuhan pidana oleh hakim, maka dapatlah dikatakan bahwa mencakup keseluruhan ketentuan perundang-undangan yang mengatur bagaimana hukum pidana itu ditegakkan atau dioprasionalkan secara konkrit sehingga seseorang dijatuhi sanksi (hukum pidana)" (Barda Nawawi Arief, 1996:129). Oleh karena itu penjatuhan pidana merupakan perwujudan pidana dalam bentuk konkret. Penjatuhan pidana hanya dapat dilakukan oleh hakim yang memeriksa perkara pidana. Dalam pemeriksaan perkara pidana ada tiga macam putusan yang dapat dijatuhkan hakim, yaitu :

1. Penjatuhan pidana (verordeling). Dalam hal ini oleh hakim diputuskan bahwa terdakwa terang salah telah melakukan peristiwa pidana yang dituduhkan kepadanya; atau 
2. Pembebasan dari penuntunan hukuman (ontslag van rechtsvervolging). Dalam hal ini Hakim memutuskan, bahwa peristiwa yang dituduhkan kepada terdakwa itu dibuktikan dengan cukup terang, akan tetapi peristiwa itu ternyata bukan peristiwa pidana atau karena tidak dapat dipertanggung jawabkan atas perbuatannya; atau

3. Putusan bebas (vrijsvraak). Putusan ini berarti, bahwa kesalahan terdakwa atas peristiwa yang dituduhkan kepadanya tidak cukup buktinya (R. Soesilo, 1996:90).

Di dalam "Dutch Criminal Justice System From A Compare Legal Prespective” dikemukakan tentang pengertian pemidanaan atau penjatuhan pidana tersebut badalah: "the statutory rules relating to penal sanctions and punishment" (L.H.C. Hulsman, 1978:320). Seacara definitive, perumusan tersebut memberikan pengertian yaitu menyangkut aturan perundang-undangan yang berhubungan dengan sanksi pidana atau pemidanaan.

Hakekat pidana adalah pembalasan, prevensi, dan campuran pembalasan prevensi dengan segala variasi dari pada ketiga aliran tersebut. Menurut Bambang Poernomo, para ahli di satu pihak berpendapat bahwa KUHP menganut paham campuran antara pembalasan dan Prevensi, akan tetapi di lain pihak terdapat bahwa KHUP manganut paham prevensi khusus (speciale preventie). Semua pandangan tersebut pada dasarnya dapat diletakkan di dalam pola dasar bahwa reaksi hukum pidana itu mempunyai dua sumber pemikiran yaitu paham revindicatieve (menuntut balas) dan paham punitieve (hukuman) sebagai berikut ini :

"Revindicatieve merupakan penderitaan sebagai akibat subyektif penderitaan dari korban yang dituntut sebagai pembalasan, yang di dalam perkembangannya diajukan persyaratan obyektif bahwa pembalasan itu harus diukur seimbang dengan kejahatan yang dilakukan, dan syarat ini merupakan persoalan tersendiri karena sukar diukur untuk dipenuhi. Punitieve mempunyai landasan juridischeschuld yang melepaskan diri dari moreleschuld dengan memberikan penderitaan sebagai tujuan terdekat guna mencapai tujuan-tujuan lainnya yang dicita-citakan masyarakat antara lain mempertahankan tata tertib hukum, melindungi benda-benda hukum dari perbuatan yang tidak semestinya, menakutkan manusia yang akan atau yang telah melanggar hukum, dan lain sebagainya" (Bambang Poernomo,1982:178)

Kemajuan yang telah dicapai dalam pemikiran tentang penjatuhan pidana sebagaimana nampak pada uraian tersebut di atas, maka kiranya dapat diharapkan peningkatan lebih lanjut, yaitu bahwa penjatuhan pidana sebagai reaksi hukum pidana sejalan dengan pemikiran baru terhadap sistem hukum pidana serta sistem penegakan hukum pidana yang berorientasai dengan perubahan-perubahan masyarakat.

Dilihat secara fungsional dan operasional pemidanaan merupakan suatu rangkaian proses dan kebijaksanaan yang konkritisasinya sengaja direncanakan melalui tahap formulasi oleh pembuat undang-undang, tahap aplikasi oleh badan/aparat yang berwenang dan tetap eksekusi oleh aparat/instansi pelaksana pidana. Agar ada keterjalinan dan keterpaduan antara ketiga tahap itu sebagai satu kesatuan system pemidanaan, diperlukan perumusan tujuan dan pedoman pemidanaan. Konsep (Rancangan KUHP 1992/1993) merumuskan bermacam-macam pedoman pemidanaan, terdiri dari:

1. Ada yang bersifat umum untuk memberikan pengarahan kepada hakim mengenai hal-hal apa yang sepatutnya dipertimbangkan dalam menjatuhkan pidana. 
2. Ada yang bersifat khusus untuk memberikan pengarahan kepada para hakim dalam memilih atau menjatuhkan jenis-jenis pidana tertentu;

3. Ada pedoman bagi hakim dalam menrapkan system perumusan ancaman pidana yang digunakan dalam perumusan delik.

\section{B. Dasar Pembenaran dan Tujuan Penjatuhan Pidana}

Dalam perkembangan hukum pidana, dikenal beberapa pandangan yang membahas tentang dasar pembenaran dan tujuan dijatuhkannya pidana kepada sesorang, Pandangan tersebut masing-masing menunjukkan dan menguatkan kebenaran dari argumentasi yang diajukan sebagai jawabannya. Pandangan tersebut dikemukakan sebagai berikut.

Berdasarkan aliran theologies (Kedaulatan Tuhan), bahwa penguasa adalah abdi Tuhan untuk melindungi yang baik. Penguasa dalam hal ini adalah negara yang berhak menentukan hukum, dan memaksa untuk mentaati hukum dengan ancaman pidana. Aliran perlindungan hukum mencari dasar pembenaran bertolak pada kegunaan dan kepentingan penerapan keputusan pidana untuk mencapai perlindungan hukum sekaligus menjamin ketertiban huk. Aliran ini dipelopori oleh Bentham, van Hamel dan Simons (E.Y.Kanter Sianturi cs, 1982:58).

Aliran Filsafat Eksistensialis memandang hanya negaralah yang berwenang memidana, negara memperoleh kewenangan itu karena telah menerima penyerahan pembatasan kebebasan individu yang dalam kenyataannya memang dibatasi oleh kebebasan individu lain. Penyerahan pembatasan kebebasan individu ini merupakan pangkal tolak wewenang negara untuk memidana (Masruhin Rubai, 1997:5). Penulis berpendapat, dengan mendasarkan pemikiran diatas, maka negara dengan kekuasaan yang melekat padanya merupakan satu-satunya yang mempunyai hak dan wewenang manjatuhkan pidana melalui alat-alatnya yang ditunjuk dalam Undang-undang yang dibuat untuk penegakan hukum pidana.

Dilihat dari tujuan penjatuhan pidana dikenal ada bebarapa macam teori tentang tujuan dijatuhkannya pidana terhadap seseorang, antara lain, teori absolute atau pembalasan, teori relative atau tujuan, teori gabungan dan teori pembinaan. Teori tersebut mempunyai sudut pandang masing-masing dalam memberikan argumentasainya terhadap pembenaran penjatuhan pidana atau tujuan diadakannya pidana. Teori absolute adalah teori yang tertua dan telah berlangsung beberapa abad. Menurut teori ini pemberian pidana dipandang sebagai pembalasan terahadap orang yang telah melakukan tindak pidana. Dalam hal ini pembalasan harus dilihat sebagai suatu reaksi keras, yang bersifat emosional dan arena itu irrasional. Menurut Nigel Welker, bahwa ada tiga pengertian mengenai pembalasan (retribution) :

1. "Retaliatory retribution" berarti dengan sengaja membebankan suatu penderitaan yang pantas diderita oleh seseorang penjahat dan yang mampu menyadari bahwa beban penderitaan itu akibat kejahatan yang dilakukannya.

2. "distributive retribution" berarti pembatasan terhadap bentuk-bentuk pidana yang dibebankan dengan sengaja terhadap mereka yang telah melakukan kejahatan. Mereka ini telah memenuhi persyaratan-persyaratan lain yang dianggap perlu dalam rangka mempertanggungjawabkan mereka tehadap bentuk-bentuk pidana;

3. "quantitative retribution" berarti pembatasan terhadap bentuk-bentuk pidana yang mempunyai tujuan lain dari pembalasan, sehingga bentuk-bentuk pidana itu tidak melampaui tingkat kekejaman yang dianggap pantas untuk kejahatan yang dilakukan (dalam Sahatepy, 1979:223-224). 
Dua tokoh lain menganut teori sbsolut adalah Immanuel Kant (1724-1804) dan George Hegel (1770-1831). Immanuel Kant memandang pidana sebagai "Kategorische Imperative" artinya seseorang harus dipidana oleh hakim karena ia telah melakukan kejahatan. Hal ini merupakan tuntutan keadilan yang absolute sebagaiman dikemukakan oleh Kant dalam bukunya "Philosophy at Law" sebagai berikut; "Pidana tidak pernah dilaksanakan semata-mata sebagai sarana untuk mempromosikan tujuan/kebaikan lain, baik bagi si pelaku itu sendiri maupun bagi masyarakat, tetapi dalam semua hal harus dikenakan hanya karena orang yang bersangkutan telah melakukan suatu kejahatan" (dalam Muladi dan Nawawi, 1992:11).

Menurut Hegel penjatuhan pidana merupakan konsekuensi logis dari kejahatan. Karena kejahatan merupakan pengingkaran terhadap hak masyarakat, kejahatan harus ditiadakan dengan pidana sebagai pembalasan, hal ini dikemukakan sebagai berikut: Teori Hegel dengan istilah "dialektische vergelding" atau pembalasan yang bersifat dialektis artinya pidana mensyaratkan adanya keseimbangan antara kejahatan yang dilakukan oleh seseorang dengan pidana yang harus dijatuhkan bagi orang tersebut. Seimbang di sini tidak berarti harus sejenis, melaikan cukup apabila pidana yang dijatuhkan bagi pelakunya itu mempunyai nilai yang sama dengan kejahatan yang telah dilakukan oleh pelakunya (dalam Lamintang, 1984:24)

Dalam pandangan teori relatif, hukum pidana bertujuan untuk mencegah dan mengurangi kejahatan. Pidana harus dimaksudkan untuk mengubah tingkah laku penjahat dan orang lain yang cenderung melakukan kejahatan. Teori ini lebih melihat ke depan, sedang teori absolute hanya memperhatikan peristiwa yang telah lalu. Aliran behavioral sebagai aliran yang bertujuan mempelajari tingkah laku manusia mengikuti teori relatif. Ada bebarapa prinsip yang dikemukakan aliran behavioral, yaitu: Pertama, adanya kebebasan kehendak merupakan hal mustahil, sebab tingkah laku manusia ditentukan oleh kekuatan yang membatasi dirinya. Kedua, tanggung jawab moral tidak beralasan, sebab kesalahan tidak dapat dianggap berasal dari tabiat, melainkan merupakan akibat dari situasi yang tak terelakkan. Ketiga, tingkah laku manusia dapat diteliti secara ilmiah dan dapat dikontrol. Keempat, fungsi hukum sepenuhnya bertujuan untuk merubah kepribadian, sehingga tabiat seseorang yang bertentangan dengan norma-norma osial tidak akan terulang dimana yang akan dating, adan apabila tidak berhasil pidana dimaksudkan untuk mencegah dilakukannya kejahatan dengan paksaan dari luar (Orland, 1973:185).

Perbedaan cirri-ciri pokok antara teori absolute (retributive) dengan teori relatif (utilitarian) diuraikan secar rinci oleh Karl O. Christiansen sebagai berikut.

1. Dalam cirri-ciri pokok teori absolute (retributive) :

a) tujuan pidana adalah semata-mata untuk pembayaran

b) pembalasan adalah tujuan utama dan di dalamnya tidak mengandung saranasarana untuk tujuan lain, misalnya untuk kesejahteraan masyarakat;

c) Kesalahan merupakan satu-satunya syarat untuk adanya pidana;

d) Pidana harus disesuaikan dengan kesalah si pelanggar;

e) Pidana melihat kebelakang; ia merupakan pencelaan yang murni dan tujuannya tidak untuk memperbaiki, mendidik atau memasyarakatkan kembali si pelanggar.

2. Sedangkan untuk ciri-ciri teori relatif (utilitarian)

a) tujuan pidana adalah pencegahan

b) pencegahan bukan tujuan akhir, tetapi hanya sebagai sarana untuk mencapai tujuan yang lebih tinggi yaitu kesejahteraan masyarakat; 
c) hanya pelanggar-pelanggar hukum yang dapat dipersalahkan kepada si pelaku saja(misalnya karena sengaja atau culpa) yang memenuhi syarat untuk adanya pidana;

d) pidana harus ditetapkan berdasarkan tujuan sebagai alat untuk pencegahan kejahatan

e) pidana melihat kemuka (bersifat prespektif) pidana mengandung unsur pencelaan, tetapi baik pencelaan maupun unsur pembalasan tidak dapat diterima apabila tidak membantu pencegahan kejahatan untuk kepentingan kesejahteraan masyarakat (dalam Muladi dan Arief Barda Nawawi, 1992:184:17).

Ada dua paham mengenai teori pencegahan, yaitu teori pencegahan umum dan teori pencegahan khusus. Pencegahan umum dimaksudkan untuk mempengaruhi orang pada umumnya agar tidak melakukan tindak pidana. Pengaruh ini dapat berasal dari ancaman pidana maupun dari pelaksanaan pidana. Pencegahan khusus dimaksudkan untuk mempengaruhi orang telah melakukan tindak pidana agar tidak mengulangi lagi melakukan tindak pidana. Pengaruh demikian dapat berasal dari rasa jera atau mungkin telah timbul kesadaran atas kesalahan, bergantung pada bentuk pidana yang dijatuhkan.

Teori gabungan berpandangan bahwa penjatuhan pidana dilakukan atas asas pembalasan dan asas mempertahankan tata tertib hukum masyarakat. Ada tiga dasar pemikiran yang diajukan dalam teori ini.

1. Mentitik beratkan pada pembalasan, tetapi pembalasan tersebu tidak boleh malampaui batas dan cukup untuk dapat mempertahankan tata tertib

2. Mentitik beratkan pada pertahanan tata tertib masyarakat. Penjatuhan pidana bertujuan untuk mempertahankan tata tertib masyarakat, namun penderitaan atas pidana yang dijatuhkan tidak boleh lebih berat dari pada perbuatan yang dialkukan oleh terpidana

3. Pidana memenuhi keharusan pembalasan dan keharusan melindungi masyarakat, memberikan titik berat yang sama antara pembalasan dan perlindungan kepentingan masyarakat (Made Sadhi Astuti, 1997:33)

Sudut pandang teori pembinaan adalah bahwa tujuan pidana adalah untuk merubah tingkah laku (kepribadian) terpidana agar ia meninggalkan kebiasaan jelek yang bertentangan dengan norma-norma hukum serta norma-norma lainnya agar supaya ia lebih cenderung untuk mematuhi norma-norma yang berlaku. Dengan kata lain tujuan pidana untuk memperbaiki narapidana. Perkembangan teori ini adalah perkembangan filsafat kemanusiaan dan perhatiannya terhadap kesejahteraan manusia (Carney, 1974:66)

Dalam teori pidana kebijaksanaan yang ditunjukkan terhadap anak, tujuan pidana dikemukakan adalah untuk: "(1) perlindungan terhadap masyarakat, (2) perlindungan terhadap pelaku tindak pidana anak, (3) memupuk solidaritas antara keluarga dengan masyarakat dalam rangka membina, memelihara dan mendidik pelaku tindak pidana anak, dan (4) pencegahan umum dan khusus (Made Sadhi Astuti, 1997:159). 


\section{P E M B A H A S A N}

\section{A. Penerapan Hukuman Pidana Penjara Untuk Anak Nakal Dalam Sistem Peradilan Pidana Anak.}

Dalam sejarah perkembangan sistem pertanggungjawaban pidana terhadap seseorang yang berusia belum dewasa (anak-anak) didasarkan pada kemampuan bertanggungjawab, disamping ditentukan batas-btasa umur tertentu. Ketidakmampuan bertanggungjawab terhadap anak didasarkan kepada anak itu sudah dapat membedakan yang baik dan yang buruk (oordeel des onderscheid).

Pada sistem Code Penal di Nederland sampai pada tahun 1886 sampai pada tahun 1918 (di Ned. Indie) mengunakan adanya pembatasan umur. Dikatakan seseorang anak yang belum mencapai usia enam belas (16) tahun melakukan sesuatu tindak pidana, tidak dipidana, akan tetapi anak itu dapat diperintahkan oleh hakim untuk mendapat pendidikan paksa dari pemerintah (E.Y. Kanter Sianturi \& S.R. Sianturi, 1982:264) Kemudian dapat dijelaskan jika anak itu sudah berusia 16 tahun tetapi belum mencapai dua puluh satu (21) tahun, hakim harus menyelidiki apakah anak itu sudah mencapai akal yang dapat membedakan yang baik dan yang buruk (berakal). Jika ternyata sudah berakal, maka terhadap anak itu sesuai dengan asas peradilan, dapat dipidana tetapi harus mendapat pendidikan paksa.

Di Negeri Belanda sendiri, pada tahun 1886, semenjak berlakunya Kitab Undang-undang Hukum Pidana Nasional Belanda, yang dalam banyak hal mencontoh KUHP Jerman, terjadi perubahan dalam batasan usia sebagai berikut :

1. jika seorang anak yang usianya antara 10 tahun, melakukan sesuatu tindak pidana, tidak dipidana, akan tetapi harus mendapat pendidikan paksa dari pemerintah;

2. jika seorang anak yang usianya antara 10 tahun dan 16 tahun melakukan suatu tindak pidana, dan sudah berakal (oordeel des onderscheid) anak itu harus dipidana dengan pengurungan 1/3 nya. Tetapi jika belum berakal anak itu tidak dipidana, akan tetapi harus diperintahkan oleh hakim pidana untuk dididk paksa oleh pemrintah, sampai anak itu berumur 18 tahun;

3. seorang anak yang sudah berusia 16 tahun atau lebih, jika melakukan suatu tindak pidana, harus dipidana. Semenjak tahun 1905 di Nederland terjadi lagi perubahan dengan mengadakan tersendiri Kinderwetten, yang dapat dibagi menjadi :

4. Strafrechtelijke kinderwet;

5. Penitentaire kinderwet of kinderbeginselenwet;

6. Bugerlijkeke Kinderwet (E.Y Kanter \& S.R. Sianturi, 1982:265)

Perubahan tersebut pada pokoknya adalah mengenai pembatasan usia kurang dari 10 tahun dihapuskan, sehingga secara teoritis, anak-anak dalam segala umur dapat dipidana (ini tidak berarti bahwa hakim harus menjatuhkan pidana, tetapi dapat juga hanya menjatuhkan suatu ketentuan perbaikan); bila jiwanya sehat, ia dipandang mampu bertanggungjawab dan dapat dituntut (berarti ukuran berakal ditinggalkan); batas umur belum dewasa dari 16 tahun dinaikkan menjadi 18 tahun.

Di negara-negara Asia, pada tahun 1953 berdasarkan laporan dari Miss Katayun H.Cama, seorang Hakim Anak Bombay (India), mengadakan research untuk Departemen Sosial dari PBB atas permintaan Social Commission dan Economic and Social Council, merincikan bahwa:

"Di Birma, Ceylon, India dan Pakistan seorang anak dibawah umur 7 tahun tidak dapat dinyatakan melakukan kejahatan atau pelanggaran, di Jepang tindak pidana atau pelanggaran yang dilakukan oleh anak yang kurang dari 14 tahun 
tidak dapat dihukum, di Philipina anak-anak di bawah umur 9 tahun dan Muang Thai anak-anak di bawah umur 7 tahun tidak dapat dipertanggungjawabkan secara criminal" (dalam BPHN, 1977:22).

Dalam hal tersebut, ada sifat kekhususan tidak dapat dipertanggungjawabkan di atas usia diatas yaitu dalam hal, anak diantara umur 7 tahun dan di bawah umur 12 tahun untuk di negara Birma, Ceylon, India dan Pakistan, anak diantara umur 9 tahun dan di bawah umur 15 tahun tidak dapat dipertanggungjawabkan atas tindak pidana yang dilakukannya apabila pada waktu melakukannya belum dapat menghayati, bahwa apa yang dilakukan adalah salah.

Di dalam Undang-undang No.3 Tahun 1997 memberikan perumusan secara tersendiri tentang anak dalam kaitannya dengan pertanggungjawaban pidana terahadap tindak pidana yang dilakukannya. Dengan demikian tidak lagi berpegang pada ketentuan yang diatur dalam Pasal 45, Pasal 46, dan Pasal 47 Kitab Undang-Undang Hukum Pidana. Sebagaimana dikemukakan oleh Bagir Manan:

Ketika Undang-Undang Pengadilan Anak secara sah diberlakukan, menyatakan bahwa Undang-Undang No.3 Tahun 1997 Tentang Pengadilan Anak disahkan mulai berlaku pada tanggal 3 Januari 1997, dan dilakukan penundaan hingga berlakunya tahun 1998. Undang-Undang ini dimaksud sebagai pengganti Pasal 45, Pasal 46, Pasal 47 Kitab Undang-Undang Hukum Pidana (KUHP) yang isinya memuat hal-hal baru dan lebih lengkap yang belum terdapat dalam ketentuan lama (dalam Departemen Kehakiman, 1997-I).

Penjatuhan pidana penjara adalah upaya penegakan salah satu sanksi yang dikenal hukum pidana, yang dijatuhkan atas diri seseorang yang terbukti bersalah melakukan tindak pidana. Menurut ketetapan Pasal 10 Kitab Undang-Undang Hukum Pidana (KUHP), jenis pidana irtu terdiri dari : pidana pokok dan pidana tambahan. Pidana pokok terdiri dari : pidana mati, pidana penjara seumur hidup atau pidana penjara sementara, pidana kurungan dan pidana denda. Sementara pidana tambahan, berupa: pencabutan bebarapa hak tertentu, perampasan barang tertentu, dan pengumuman keputusan hakim.

Dengan berlakunya Undang-Undang No 3 Tahun 1997 Tentang Pengadilan Anak memiliki ciri yang khusus terhadap penjatuhan pidana bagi anak dalam hukum pidana positif, dimana tidak mengikuti ketentuan pidana Pasal 10 KUHP, dan mengatur sanksinya secara tersendiri. Pidana pokok menurut Undang-Undang No 3 Tahuyn 1997 (Tentang Pengadilan Anak) dalam Pasal 23 terdiri dari:

1. Pidana Penjara (maksimum 10 tahun)

2. Pidana Kurungan,

3. Pidana Denda, atau,

4. Pidana Pengawasan.

Terhadap anak yang melakukan tindak pidana seberat apapun tidak dapat dijatuhi pidana mati, maupun penjara seumur hidup. Maksimal pidana penjara yang dapat dijatuhkan terhadap anak maksimal 10 tahun. Ini berarti secara normatif tidak boleh melebihi dari jumlah tersebut.

Jenis pidana baru dalam Kitab Undang-Undang ini adalah pidana pengawasan yang tidak diatur dalam Kitab Undang-Undang Hukum Pidana. Untuk pidana tambahan bagi anak, dapat berupa :

1. perampasan barang-barang tertentu, dan atau,

2. pembayaran ganti kerugian.

Ancaman pidana yang dapat dijatuhi terhadap anak nakal yang telah terbukti berasalah melakukan tindak pidana sesuai Pasal 26 (1) Undang-Undang No 3 Tahun 
1997 paling lama setengah dari maksimum ancaman pidana penjara bagi orang dewasa. Dalam hal tindak pidana yang dilakukan diancam dengan pidana mati atau penjara seumur hidup, maka khusus untuk anak ancaman pidana maksimum 10 (sepuluh) tahun. Dengan ketentuan Pasal 26 ini, maka ketentuan-ketentuan dalam KUHP tentang ancaman pidana bagi anak setengah dari ancaman hukuman bagi orang dewasa.

Pasal 26 UU.No 3 Tahun 1997.

1. Pidana penjara yang dapat dijatuhkan kepada anak nakal sebagaimana dimaksud dalam Pasal 1 angka 2 huruf a, paling lama 1/2 (satu per dua) dari maksimum ancaman pidana penjara bagi oerang dewas.

2. Apabila Anak Nakal sebgaimana dimaksud dalam Pasal 2 huruf a, melakukan tindak pidana yang diancam dengan pidana mati atau pidana seumur hidup, maka pidana penjara yang dapat dijatuhkan kepada anak tersebut paling lama 10 (sepuluh) tahun.

3. Apabila Anak Nakal sebagaimana dimaksud dalam Pasal 1 angka huruf 2 a, belum mencapai umur 12 (dua belas) tahun melakukan tindak pidana yang diancam pidana mati atau pidana penjara seumur hidup, maka terhadap Anak Nakal tersebut hanya dapat dijatuhkan tindakan sebagaimana dimaksud dalam Pasal 24 ayat (1) huruf b.

Bagi anak nakal yang belum mencapai umur 12 (dua belas) tahun dan melakukan tindak pidana yang diancam dengan pidana mati atau penjara seumur hidup, sesuai dengan Pasal 24 (1) huruf a dalam UU.No 3 Tahun 1997, maka terhadapnya tidak dapat dijatuhkan pidana, melainkan menyerahkan anak itu kepada negara untuk mengikuti pendidikan, pembinaan dalam latihan kerja.

Pasal 24 UU.No 3 Tahun 1997.

1. Tindakan yang dapat dijatuhkan kepada Anak Nakal ialah

a. mengembalikan kepada orang tua, wali, atau orang tua asuh;

b. menyerahkan kepada negara untuk mengikuti pendidikan, pembinaan, dan latihan kerja; atau

c. menyerahkan kepada Departemen Sosial Kemasyarakatan yang bergerak di bidang pendidikan, pembinaan dan latihan kerja.

2. Tindakan sebagaimana dimaksud dalam ayat (1) dapat disertai dengan teguran dan syarat tambahan yang ditetapkan oleh Hakim.

Dalam hal pidana penjara yang dapat dijatuhkan kepada anak maksimal 2 (dua) tahun, maka sesuai dengan ketentuan Pasal 29 Undang-Undang No.3 Tahun 1997, hakim dapat menjatuhkan pidana bersyarat, ini sepenuhnya bergantung pada hakim untuk menjatuhkan pidana bersyarat atau tidak. Apabila dijatuhkan pidana bersyarat, maka ditentukan syarat umum dan syarat khusus. Syarat umum, adalah anak nakal tidak akan melakukan tindak pidana lagi selama menjalani masa pidana bersyarat. Sementara syarat khusus, misalnya tidak boleh mengemudikan kendaraan bermotor atau wajib mengikuti kegiatan-kegiatan yang diprogramkan Balai Pemasyarakatan (BAPAS) (Prinst Darwan, 1997:25)

Pasal 29 UU. No.3 Tahun 1997:

1. Pidana bersyarat dapat dijatuhkan oleh hakim, apabila pidana penjara yang dijatuhkan paling lama 2 (dua) tahun,

2. Dalam putusan pengadilan mengenai pidana bersyarat sebagaimana dimaksud dalam ayat (1) ditentukan syarat umum dan syarat khusus. 
3. Syarat umum ialah bahwa Anak Nakal tidak akan melakukan tindak pidana lagi selama menjalani masa pidana bersyarat.

4. Syarat khusus iaolah untuk melakukan atau tidak melakukan hal tertentu yang ditetapkan dalam putusan hakim dengan tetap memperhatikan kebebasan anak.

5. Masa pidana bersyarat bagi syarat khusus lebih pendek dari masa pidana bersyarat bagi syarat umum.

6. Jangka waktu masa pidana bersyarat sebagaimana dimaksud dalam ayat (1) paling lama 3 (tiga) tahun.

7. Selama menjalani masa pidana bersyarat, Jaksa melakukan pengawasan, dan Pembimbing Kemasyarakatan melakukan bimbingan agar Anak Nakal menepati persyaratan yang ditentukan.

8. Anak Nakal yang menjalani pidana bersyarat dibimbing oleh Balai Pemasyarakatan dan bersetatus sebagai Klien Pemasyarakatan.

9. Selama Anak Nakal bersetatus sebagai Klien Pemasyarakatan dapat mengikuti pedidikan sekolah.

Jadi syarat umum tidak mengulangi tindak pidana lagi sedangkan syarat khusus, yaitu melakukan atau tidak melakukan hal-hal tertentu yang ditetapkan dalam putusan. Masa syarat khusus lebih pendek dari syarat umum dan paling lama 3 (tiga) tahun. Selama menjalani pidana bersyarat, pengawasan terhadap anak nakal dilakukan oleh Jaksa Penuntut Umum, sementara bimbingan dilakukan oleh pembimbing kemasyarakatan.

Disamping itu juga diatur pidana kurungan yang dapat dijatuhkan kepada anak nakal sesuai dengan ketentuan Pasal 1, angka 2 huruf a UU No. 3 Tahun 1997, paling lama (maksimum) setengah dari maksimum ancaman pidana kurungan bagi orang dewasa. Demikian juga dalam hal pidana denda yang dapat dijatuhkan kepada anak nakal (Pasal 28) adalah setengah dari maksimum ancaman pidana denda bagi orang dewasa. Apabila denda itu ternyata tidak dibayar, maka wajib diganti dengan wajib latihan kerja paling lama 90 hari (sembilan puluh) hari kerja dengan jam kerja tidak lebih dari 4 (empat) jam sehari dan tidak boleh dilaksanakan pada malam hari. Ketentuan ini mengikuti Pasal 4 Permanaker No: Per-01/Men/1987, yang menentukan anak yang terpaksa bekerja tidak boleh lebih dari 4 (empat) jam sehari, tidak bekerja pada malam hari (Prinst Darwan, 1997:37).

\section{B. Pembangunan Substansi Hukum Pidana Penjara Bagi Anak Dan Pencegahan Kejahatan Terhadap Anak Nakal.}

Pembangunan hukum Nasional, termasuk didalamnya pembangunan hukum, tidak selayaknya dilihat dan dipahami hanya sebagai subyek pembangunan, tetapi juga sekaligus sebagai obyek pembangunan.

Sebagai subyek pembangunan, hukum dituntut agar dapat tidak hanya berfungsi sebagai sarana pembangunan (Law is a tool of social engineering), tetapi sebagai upaya menciptakan system hukum nasional, maka dalam pembangunannya dibutuhkan pola pikir, yang melihat hukum dan memahami hukum sebagai suatu system, yaitu system hukum nasional, yang dibangun dengan cara antara lain menerapkan prinsip "good governance" dan dilakukan untuk menyesuaikan diri 
dengan perubahan system politik dan ketatanegaraan sesuai dengan amandemen UUD 1945.

Dalam kedudukanya sebagai obyek pembangunan nasional, maka pembangunan hukum, apalagi pembangunan yang berbasis APBN, maka dalam pelaksanaan pembangunannya dimasa datang, dibutuhkan tidak hanya Visi dan Misi yang jelas, namun sekaligus dan lebih penting lagi adalah pemikiran (konsepsi), tentang indikator-indikator dan pengukuran kinerja keberhasilannya yang jelas, serta pengawasan yang baik dan dengan pembiayaan yang cukup.

Perubahan paradigma dalam kehidupan politik dan ketatanegaraan di Indonesia, yaitu dari sistem otoritarian kepada sistem demokrasi dan dari sistem sentralisitik kepada sistem desentralisasi, akan berdampak pada sistem hukum yang dianut selama ini yang menitik beratkan kepada produk-produk hukum yang lebih banyak berpihak kepada kepentingan penguasa dari pada kepentingan rakyat, dan produk hukum yang lebih mengutamakan kepentingan pemerintah pusat dari kepentingan pemerintah daerah.

Oleh karena itu, pembangunan hukum nasional tidak sekedar diarahkan bagi terwujudnya system hukum yang menjamin berfungsinya hukum sebagai sarana perubahan social, tetapi melalui pembangunan nasional, dapat diciptakan system hukum nasional bagi terwujudnya kesejahteraan masyarakat secara keseluruhan, antara lain menjadi dasar hukum yang dapat mencegah dan menyelesaikan konflik-konflik yang terjadi dalam proses pembangunan.

Penjatuhan pidana penjara terhadap pelaku kejahatan adalah salah satu jenis sanksi dalam hukum pidana yang digunakan dalam upaya penanggulangan kejahatan. Oleh karena itu dalam perkembangannya, penjatuhan pidana menjadi perhatian para ahli dalam bidang hukum pidana dimana pidana penjara mempunyai peranan penting dalam menghadapi masalah kejahatan, sebagaimana dikemukakan bahwa:

1. Penggunaan hukum pidana harus memperhatikan tujuan pembangunan nasional, yaitu mewujudkan masyarakat adil makmur yang merata materiil dan spritual berdasarkan Pancasila, sehubungan dengan ini maka penggunaan pidana bertujuan untuk menanggulangi kejahatan, demi kesejahteraan dan penganyoman masyarakat;

2. Perbuatan yang diusahakan untuk dicegah harus merupakan perbuatan yang tidak dikehendaki, yaitu perbuatan yang mendatangkan kerugian (material dan atau spiritual) atas warga masyarakat;

3. Pengunaan hukum pidana harus pula mempertimbangkan prinsip "biaya dan hasil" (cost benfit principle);

4. Pengunaan hukum pidana harus pula memperhatikan kapasilitas atau kemampuan daya kerja dari badan-badan penegak hukum, yaitu jangan sampai ada kelampauan beban tugas (overbelasing) (Sudarto, 1977:48).

Dalam upaya penangulangan kejahatan pidana penjara tidak hanya ditujukan kepada orang dewasa (Pasal 10 KUHP), akan tetapi juga terhadap anak yang melakukan tindak pidana, hal ini dapat dibaca di dalam Undang-Undang No. 3 Tahun 1997, dalam Pasal 26 ayat 1 menentukan, "pidana penjara yang dapat dijatuhkan kepada anak nakal sebagaimana dimaksud dalam Pasal 1 angka 2 hurf a, paling lama 1/2 (satu per dua) dari maksimum ancaman pidana penjara bagi orang dewas". Dalam 
penjelasan Undang-Undang No. 3 Tahun 1997 Tentang Pengadilan Anak, dikemukakan dengan adanya pembedaan dan perlakuan ancaman pidana penjara antara anak dan orang dewasa, dikarenakan untuk melindungi dan mengayomi anak agar menyongsong masa depan anak yang masih panjang, dan memberi kesempatan pada anak agar melalui pembinaan akan memperoleh jati dirinya untuk menjadi manusia yang mandiri, bertanggung jawab dan berguna bagi diri, keluarga, bangsa dan bernegara.

Menurut Made Sahdi Astuti, penerapan pidana perampasan kemerdekaan terhadap anak dalam ketentuan SMR-JJ Rule 9.1 dan Rule 17.1 menganut penerapan kebijaksanaan selektif dan limitataif, hal ini mengingat pertumbuhan fisik dan jiwa anak. Ketentuan tersebut mengatur sebagai berikut :

17.1. (b). Rectriction on the personal liberty of the juvenile shall be imposed only after careful consideration and shaall limited to the possible minimum;

17.2. (c). Deprivation of personal liberty shaall not be imposed unless the Juvenile is adjudicated of a serious act involving violence against another person or of persistence in commiting other serious offence and unless there is no other appropriate response;

19.1. The placement of a juvenile in an institution shall always be disposition of last resort and for minimum necessary periode.

Rule 17.1 (b) ditegaskan, bahwa pembatasan-pembatasan terhadap kebebasan pribadi anak hanya dikenakan setelah mempertimbangkan dengan hati-hati dan dibatasi seminimal mungkin. Sedangkan di dalam Rule 17.1 (c) ditentukan, bahwa perampasan kebebasan atau kemerdekaan pribadi tidak akan dikenakan kecuali kalau anak telah diputuskan melakukan tindakan kekerasan yang serius terhadap orang lain atau terus-menerus melakukan tindak pidana serius dan kecuali tidak ada bentuk sanksi lain yang lebih tepat. Sedangkan dalam Rule 19.1 ditentukan, bahwa menempatkan seorang anak dalam suatu lembaga akan selalu menjadi penempatan dari usaha terakhir dan untuk waktu mini9mal yang ditentukan (Made Sadhi Astuti, 1997:151-152).

Dalam konsep rancangan KUHP Nasional (1972), penggunaan upaya pidana tersebut juga masih diperlakukan, sebagaimana ditentukan yaitu :

Dalam Pasal 2 ayat 1 :

1. Untuk mencegah dilakukannya tindak pidana demi penganyoman negara, masyarakat dan penduduk.

2. Untuk membimbing agar terpidana insyaf dan menjadi anggota masyarakat yang berbudi baik dan berguna;

3. Untuk menghilangkan noda-noda yang diakibatkan oleh tindak pidana.

Pasal 2 ayat 2: bahwa pemidanaan tidak dimaksudkan untuk menderitakan dan merendahkan martabat manusia. Dari perumusan tersebut, bahwa pemberian pidana melihat ke depan. Perumusan ini memperlihatkan pengaruh dari aliran Defense Sociale, atau aliran yang merupakan pertumbuhan lanjut dari aliran moderen. Aliran moderen menitikberatkan perhatiannya kepada orang yang melakukan tindak pidana dengan maksud untuk melindungi masyarakat terhadap bahaya yang ditimbulkan oleh pembuat. Perlindungan masyarakat adalah tujuan semua pemidanaan, yaitu: "(1) mencegah dilakukannya tindak pidana baik oleh orang dewasa maupun anak demi 
penganyoman masyarakat (2) melindungi masyarakat terhadap sifat berbahaya sepembuat dewasa ataupun anak, dan (3) melindungi masyarakat dari bahaya pengulangan tindak pidana yang dilakukan oleh orang dewasa maupun anak (Made Sadhi Astuti, 1997:151-152).

Aliran Defense Sociale secara aktif hendak menghilangkan bahaya terhadap masyarakat dengan mengadakan resosialisasi dari pembuat. Pidana hendaknya dipertahankan sebgai salah satu sarana untuk social defence dalam arti melindungi masyarakat terhadap kejahatan dengan memperbaiki atau memulihkan kembali (rehabilitatie) pelaku tanpa mengurangi keseimbangan perorangan (pembuat) dan masyarakat (Sudarto, 1977:59). Menurut Fauconnet, bahwa upaya penggunaan pidana adalah dalam rangka penegasan kembali nilai-nilai yang ada dalam masyarakat yang telah dilanggar dan dirubah oleh adanya kejahatan. Pendapat ini dikemukakan, bahwa "the cinviction and execution of the sentences is ensentially aceremonial reaffirmation of the societal values that are violated and challenged by the crime" (dalam Karl $\mathrm{O}$ Christiansen, 1976:60).

Ted Honderich berpendapat bahwa suatu pidana dapat disebut sebagai alat pencegah yang ekonomis (economical deterrents) apabila memenuhi syarat-syarat sebagai berikut:

1. Pidana itu sunguh-sungguh mencegah

2. Pidana itu tidak menyebabkan timbulnya keadaan yang lebih berbahaya atau merugikan dari pada yang akan terjadi apabila pidana itu tidak dikenakan;

3. Tidak ada pidana lain yang dapat mencegah secara efektif dengan bahaya atau kerugian yang lebih kecil (Barda Nawawi Arief, 1996:39)

Pandangan Bassiouni, bahwa dalam menjatuhkan pidana harus memperhatikan kebutuhan untuk melindungi dan mempertahankan kepentingan-kepentingan masyarakat. Pidana hanya dibenarkan apabila ada kebutuhan yang berguna bagi masyarakat dan terwujudnya kepentingan-kepentingan sosial yang mengandung nilainilai tertentu yang perlu dilindungi. Kepentingan-kepentingan sosial tersebut adalah :

1. Pemeliharaan tertib masyarakat

2. Perlindungan warga masyarakat kembali dari kejahatan, kerugian atau bahaya yang tidak dapat dibenarkan, yang dilakukan oleh orang lain;

3. Memasyarakatkan kembali (resosialisasi) para pelanggar hukum;

4. Memelihara atau mempertahankan integritas pandangan-pandangan dasar tertentu mengenai keadilan social, martabat kemanusiaan dan keadilan individu (dalam Barda Nawawi Arief, 1996:40)

Pendekatan humanistis dalam penggunaan pidana oleh satu negara sebagai upaya penanggulangan kejahatan tidak hanya berarti bahwa pidana yang dikenakan kepada sipelanggar harus sesuai dengan nilai-nilai kemanusiaan (falsafah hidup), tetapi juga harus dapat membuktikan kesadaran sipelanggar akan nilai-nilai kemanusiaan dan nilai-nilai pergaulan hidup dalam masyarakat, sebagaiman diungkapkan, "the very foundation of any criminal justice system consist of the philosophy behind a given country" (W.Clifford, 1973:6).

Dewasa ini dibeberapa negara maju seperti Amerika Serikat, masalah pemidanaan terhadap anak lebih banyak menggunakan lembaga probation (menjalani masa percobaan) yang dapat diterapkan pada tingkat pemeriksaan di kepolisian juga pada putusan pengadilan dengan maksud agar pembinaan anak dapat dilakukan dengan pengawasan tanpa memisahkan anak dengan keluarga dan masyarakat sebagai cara yang terbaik. Hal ini sering dilakukan sebagaimana dikemukakan: "probation officers 
who recommend and lawyers who support without challenge-the detenition or commitment of young ster to an institution where he will be preyed upon, and in other ways made bitter rather better" (Alan R. Coffey.1974:52).

\section{PENUTUP}

\section{A. Kesimpulan}

1. Di Indonesia dengan diberlakukannya Undang-undang Nomor 3 tahun 1997 Tentang Pengadilan Anak telah membawa perubahan baru tentang ketentuan pidana penjara bagi anak, sehingga ketentuan Kitab Undang-undang Hukum Pidana (Pasal 10 KUHP) tentang jenis hukuman dan Pasal 45, Pasal 46, dan Pasal 47 KUHP tidak lagi digunakan untuk anak. Pidana penjara merupakan bagian dari penegakan hukum pidana terhadap anak-anak nakal, dalam upaya penanggulangan kejahatan untuk dapat dilakukan pembinaan, dan penjatuhan hukuman sepenuhnya berada dalam kekuasaan hakim. Adapun dasar pertimbangan hakim menjatuhkan pidana perampasan kemerdekaan terhadap anak adalah: (1) melakukan tindak pidana lebih dari satu kali, (2) melakukan kejahatan berat, (3) dipandang tidak dapat diperbaiki lagi,dan (4) membahayakan masyarakat.

2. Pidana penjara yang dapat dijatuhkan kepada anak nakal sebagaimana dimaksud dalam Pasal 1 angka 2 huruf a, paling lama 1/2 (satu per dua) dari maksimum ancaman pidana penjara bagi orang dewasa. Apabila Anak Nakal melakukan tindak pidana yang diancam dengan pidana mati atau pidana seumur hidup, maka pidana penjara yang dapat dijatuhkan kepada anak tersebut paling lama 10 (sepuluh) tahun. Apabila Anak Nakal belum mencapai umur 12 (dua belas) tahun melakukan tindak pidana yang diancam pidana mati atau pidana penjara seumur hidup, maka terhadap Anak Nakal tersebut hanya dapat dijatuhkan tindakan sebagaimana dimaksud dalam Pasal 24 ayat (1) huruf $b$.

\section{B. Saran-saran}

1. Perlu ditinjau kembali batas umur terhadap anak yang dapat dikenakan pidana penjara, dan pengenaan pidana penjara terhadap anak perlu dibangun paradigma yang sesuai dengan nilai-nilai yang hidup di dalam peradaban dan kultur masyarakat Indonesia.

2. Pemidanaan terhadap anak ke depan sangat perlu menggunakan lembaga probation (menjalani masa percobaan) yang dapat diterapkan pada tingkat pemeriksaan di kepolisian juga pada putusan pengadilan dengan maksud agar pembinaan anak dapat dilakukan dengan pengawasan tanpa memisahkan anak dengan keluarga dan masyarakat sebagai cara yang terbaik.

\section{DAFTAR PUSTAKA}

Arif Fakrulloh, Zudan, Materi Kuliah Hukum Sumber Daya Alam dan Perencanaan Pembangunan, Program Doktor Ilmu Hukum Untag Surabaya, 2010.

Ancel, Marc (1965) Social Defence, A modern approach to criminal problems Routledge \& Paul Kegan, London. 
BPHN (1976) Loka Karya Evaluasi Bimbingan Kemasyarakatan dan Pengentasan Anak, Binacipta, Jakarta.

BPHN (1977) Loka Karya Tentang Peradilan Anak, Bina Cipta Bandung.

BP7 Pusat (1995) Bahan Penataran Pedoman Penghayatan dan Pengamalan Pancasila, UUD 1945, GBHN, Jakarta

Barda, Arief Nawawi (1994) Kebijakan Legislatif Dalam Penanggulangan Kejahatan Dengan Hukum Pidana. Ananta, Semarang.

, (1992) Teori-teori Dan Kebijakan Pidana (Edisi Revisi), Alumni, Bandung.

(1998) Beberapa Aspek Kebijakan Penegakan Dan Pengembangan Hukum Pidana, Citra Aditya Bakti, Bandung.

Clifford, W. (1973) Reform in Criminal Justice in Asia and the Far East, Resource Meterial Series No.6 Unafei, Tokyo.

Chandra Muzaffar (1995), Hak Azasi Manusia Dalam Tata Dunia Baru, Mizan, Bandung.

Coffey, Alan R. (1974) Juvenile Justice as a System Law Enforcement To Rehabilitation, Prentice Hall, The United States of Amerika.

Darwan, Prinst (1997) Hukum Anak Di Indonesia, Citra Aditya Bakti, Bandung.

Hulsman L.H.C. (1978) The Duth Criminal Justice System From A Comperative Legal Perspective, In D.C Fokema ed. Introduction to Dutch Law For Foreign Lawyers, Kluwe Deventer, Nederlands.

Jackson, RM. (1972) Enforcing the Law, Pelican Book, USA.

J. Henham. Ralph (1999) Crimi9nal Justice on Sentencing Policy, Dartmouth Publising Company limited, USA.

J. William, Chambliss \& Robert B. Seidman (1971) Law, Order, and Power, AddisonWesley Publishing Company, USA.

Johnson, Alvin.S. (1994) Sosiologi Hukum, Rineka Cipta, Jakarta.

Johnston, Norman, et.al., (1973) The Sociologiof Punishment \& Correction, John Wiley and Sons, New York.

Kusumah, Mulyana W. (1986) Hukum dan Hak-hak Anak, CV. Rajawali, Jakarta.

---------, (1982) Analisa Kriminologi Tentang Kejahatan-Kejahatan Kekerasan, Ghalia Indonesia, Jakarta. 
Orland, Leonard (1973) Justice, Punishment, Treatment The Correctional Proces, Free Press, New York.

Ross, Alf (1975) On Guality, Responsibility and Punishment, Steven \& Sons Ltd.

Rubai, Masruchin (1997) Mengenal Pidana dan Pemidanaan Di Indonesia, Penerbit IKIP, Malang.

Sadhi, Astuti Made (1998) Peranan Hakim Dalam Peradilan Pidana Untuk Mewujudkan Perlindungan Dan Kesejahteraan Anak, Pidato Pengukuhan Jabatan Guru Besar Dalam Ilmu Hukum, Fakultas Hukum UNIBRAW, Malang.

Soesilo, R. (1974) Kitab Undang-undang Hukum Pidana, Serta Komentarkomentarnya Lengkap Pasal Demi Pasal, Politea, Bogor.

Jurnal-jurnal :

Journal Crime And Deliquency. (1999) Setencing completion and Recidivism Among Juvenilies Referred to Teen Courts, Vol. 45 No. 4, October, Sage Publications, Inc. USA.

Peraturan-peraturan dan lain-lain:

Resolusi PBB (XIV), Deklarasi Hak-hak Anak, 20 November 1958.

Resolusi PBB A/RES/30/33, 1986: The Beijing Rules; United Nation Standard Minimum Rules; For The Administration of Juvenile Justice, Departemen of Public Information, New York.

Resolusi PBB Nomor 44/25 20 November 1989: Convention On The Rights of the Child, United National Children's Fund (UNICEF).

Surat Edaran Mahkama Agung (SEMA) No. 6 Tahun 1987 tg. 17 November 1887, Tentang Tata Tertib Sidang Anak.

Undang-undang Nomor 8 Tahun 1982 Tentang Kitab Undang-undang Hukum Acara Pidana.

Undang-undang Nomor 3 Tahun 1997, Tentang Peradilan Anak. 